\title{
Conflict and Contract Law
}

This article examines an under-explored reason to have contract law: conflict minimization. An important function of contract law, the article contends, is to diminish the wasted time, effort, and resources spent on disputes over economic exchange, and to reduce the incidence of harm resulting from these disputes. Minimizing conflict typically serves the parties' own interests, and it also serves the public interest in social peace. These insights have implications not just for contract law as a whole but also for its doctrinal details. The article thus discusses how several doctrines of substantive contract law help to minimize conflict, without claiming that currently prevailing contract law regimes are perfectly adapted to this aim. Finally, it defends the normative claim that conflict minimization should be considered one of contract law's goals.

Why should the state get involved in contractual disputes? It is far from obvious what justifies the use of scarce resources and the state's coercive authority to adjudicate claims of wrongdoing between parties to economic exchange. For some, contractual enforcement is necessary to protect the parties' fundamental rights to freedom or autonomy. ${ }^{1}$ Others look instead for the instrumental benefits, the valuable consequences, that contract law brings about. $^{2}$ In that vein, Arthur Corbin identified two 'chief purposes for which the remedy in damages for breach of contract is given'. ${ }^{3}$ Corbin's first purpose was, and is, commonplace:

\footnotetext{
${ }^{1}$ For theories of contract law based on the parties' right to autonomy, see Charles Fried, Contract as Promise: A Theory of Contractual Obligation (Harvard UP 1981); Randy E Barnett, 'A Consent Theory of Contract' (1986) 86 Colum L Rev 269; Arthur Ripstein, Force and Freedom: Kant's Legal and Political Philosophy (Harvard UP 2009) ch 5.

${ }^{2}$ See Liam Murphy, 'The Practice of Promise and Contract' in Gregory Klass, George Letsas, and Prince Saprai (eds), Philosophical Foundations of Contract Law (OUP 2014).

${ }^{3}$ Arthur Linton Corbin, Corbin on Contracts, vol 5 (2nd edn, West Publishing 1964) 23.
} 
'the prevention of similar breaches in the future'. In the decades since Corbin's remark, lawand-economics scholars have elaborated and refined the idea that contract law's purpose is to prevent—or, instead, to put an appropriate price on—-future breaches of contract. ${ }^{5}$

But Corbin identified another instrumental purpose for contractual liability: 'the avoidance of private war'. ${ }^{6}$ This second purpose has not spawned nearly so much subsequent development or reflection as the first. ${ }^{7}$ Corbin himself does not seem to have pursued the thought, ${ }^{8}$ and it appears only briefly and sporadically in philosophical discussions about contract law's foundations. These discussions remain focused instead on the relationship between promissory morality and contract law. That may be because theorists of contract law tend to eschew discussion of the realities of contract law litigation. ${ }^{9}$ While promissory morality may fit the rules and principles that appear in contract law textbooks, ${ }^{10}$ the law in

\footnotetext{
${ }^{4}$ ibid.

${ }^{5}$ Economic analysts focus not so much on the prevention of future breaches as the prevention of future inefficient breaches. For a review, see Gregory Klass, 'Efficient Breach' in Gregory Klass, George Letsas, and Prince Saprai (eds), Philosophical Foundations of Contract Law (OUP 2014).

${ }^{6}$ Corbin (n 3) 23.

${ }^{7}$ The claim may remind some readers of the 'civil recourse' account of tort law, an account Goldberg and Zipursky, its leading proponents, believe can be extended to contract law. See John CP Goldberg and Benjamin C Zipursky, 'Civil Recourse Revisited' (2011) 39 Florida State U L Rev 341, 347-56. More specifically, Nathan Oman has sought to apply a particular version of civil recourse ideas to contract law. See Nathan Oman, 'Contract as Consent to Retaliation: A Civil Recourse Theory of Contractual Liability' (2011) 96 Iowa L Rev 529. I explore the relationship between the claim in this article and civil recourse theory generally in Part 3 below, and mention some specific disagreements with Oman's particular understanding of contract law as 'consent to retaliation' at notes 114 and 132.

${ }^{8}$ It has occasionally seeped into the writings of Joseph Perillo, who updated Corbin's treatise. See Joseph M Perillo, 'Misreading Holmes on Tortious Interference' (2000) 68 Fordhcam L Rev 1085, 1092-93: 'The law seeks to protect reliance and expectancies, and to preserve peace and tranquility. Breaches - even efficient breaches - tend not only to disappoint expectations, but also to precipitate private disputes. ... [D]amages and other legal remedies are substitutes for private warfare.'

${ }^{9}$ Brian H Bix, 'The Role of Contract: Stewart Macaulay's Lessons from Practice', in Jean Braucher, John Kidwell and William C Whitford (eds), Revisiting the Contracts Scholarship of Stewart Macaulay (Hart Publishing 2013). For a qualified defence of this stance, see Stephen A Smith, Contract Theory (OUP 2004) 3435. Even beyond self-consciously theoretical works, 'most books on contract do not actually include a chapter on dispute resolution processes'. Linda Mulcahy and John Tillotson, Contract Law in Perspective (5th edn, Routledge-Cavendish 2008) 194.

${ }^{10}$ Some commentators doubt even the fit between promissory morality and the textbook rules of contract law. Seana Valentine Shiffrin, 'The Divergence of Contract and Promise' (2007) 120 Harv L Rev 708. Compare Jody S Kraus, 'The Correspondence of Contract and Promise' (2009) 109 Colum L Rev 1603.
} 
action famously diverges from law in those books. Once one considers the 'settlement culture' that pervades contemporary litigation, Corbin's idea of contract lawsuits as an alternative to private warfare immediately begins to seem a more plausible aim for contract law. Contractual disputes, like other disputes, usually end in agreed settlements, a result strongly encouraged by the legal system. ${ }^{11}$ To the extent that Corbin's second purpose has resurfaced, then, it has often arisen from reflection on empirical and historical studies of contract disputes. In the course of one such reflection, Hugh Collins suggests that 'the dominant purpose [of the regulation of contracts] should be the peaceful resolution of the dispute'. ${ }^{12}$

In a similar spirit, this article aims to defend conflict-management as a purpose for contract law. More precisely, the article shows that one of the reasons for having contract law and contract adjudication is to reduce the incidence and severity of disputes between parties to agreements to engage in economic exchange. Disputes over contracts can result in several kinds of unfortunate consequences. For one thing, the parties to a dispute must spend time and energy wrangling with one another that would otherwise be directed to more fruitful ends. Moreover, a dispute may damage, or bring to an end, an otherwise mutually beneficial relationship. Most dramatically, though violence is admittedly a remote possibility in many settings, contractual disputes do sometimes result in physical injuries and property damage. The claim is that suitably designed contract law helps to minimize these various harms.

\footnotetext{
${ }^{11}$ Stewart Macaulay, 'An Empirical View of Contract' [1985] Wisconsin L Rev 465, 470: 'Even when contract law might offer a remedy, the legal system in operation promotes giving up or settling rather than adjudicating to vindicate rights.'

${ }^{12}$ Hugh Collins, Regulating Contracts (OUP 1999) 321. David Campbell, similarly alive to the realities of dispute resolution, has made the related claim that the promotion of co-operation between the parties in response to breach should be recognized as a crucial principle of contract remedies. David Campbell, 'The Relational Constitution of Remedy: Co-operation as the Implicit Second Principle of Remedies for Breach of Contract' (2005) 11 Texas Wesleyan L Rev 455.
} 
By way of clarification: it would also be possible to propose a different version of the claim that contract law contributes to social peace. Many of the great thinkers of the Enlightenment contended that participation in commerce makes individuals and nations less prone to aggression. According to these thinkers, who include Montesquieu, David Hume, and Adam Smith, the preoccupation with honour during the feudal age brought a constant danger of conflict. But in a market setting, enlightened self-interest serves as an effective check on unruly passions. According to Albert Hirschman, who labelled this idea the 'douxcommerce thesis', '[t]here was much talk, from the late seventeenth century on, about the douceur of commerce ... sweetness, softness, calm, and gentleness ... the antonym of violence'. ${ }^{13}$ The doux-commerce thesis is a claim about markets rather than about contract law. But to the extent that contract law supports markets, one could try to justify contract law's existence on the ground that it helps to channel people towards more peaceful forms of social life. ${ }^{14}$ This article, however, does not seek to defend the claim that markets soothe conflict better than other forms of social and economic organization. ${ }^{15}$ Indeed, the article assumes that self-interested exchange relationships often contain the seeds of conflict, ${ }^{16}$ and

\footnotetext{
${ }^{13}$ Albert O Hirschman, The Passions and the Interests: Political Arguments for Capitalism Before its Triumph (Princeton UP 1977) 59.

${ }^{14}$ For a recent argument along these lines, see Nathan B Oman, The Dignity of Commerce: Markets and the Moral Foundations of Contract Law (University of Chicago Press 2016). Oman contends that contract law supports well-functioning markets, and that well-functioning markets 'provide a framework for peaceful and productive cooperation in the face of the pervasive pluralism of contemporary society'. ibid 40.

${ }^{15}$ A long-established line of political thought - oddly enough, barely mentioned by Oman (n 14) - argues for the opposite conclusion. Karl Marx, Capital: A Critique of Political Economy, vol 1 (first published 1867, Penguin Books 1976). Pashukanis's Marxist theory of law, for example, takes as one of its assumptions that the parties to capitalist exchange relationships are inherently antagonistic to one another. Evgeny Pashukanis, 'General Theory of Law and Marxism: Chapter 5' in Evgeny Pashukanis, Selected Writings on Marxism and Law (Academic Press 1980).

16 'Exchanges are peacefully resolved wars, and wars are the result of unsuccessful transactions'. Claude LéviStrauss, The Elementary Structures of Kinship (first published 1949, Eyre \& Spottiswoode 1969) 67.
} 
that the best hope for legal and social institutions is to manage conflict, rather than to try to eliminate it. $^{17}$

Some degree of contractual conflict is inescapable, even healthy; but, as Ian Macneil points out, 'uncontrolled conflict is the antithesis of continuing social behaviour'. ${ }^{18}$ The questions the article addresses are as follows: assuming a certain level of self-interested economic exchange, does contract law help to control conflict over that exchange? If so, what particular features of contract law tend to support this aim? And should conflict management rightly be considered a goal for contract law? Answering these questions in turn, the article provides evidence in section 1 that contract law contributes to conflict-minimization. In section 2, the article moves from the institution of contract law as a whole to particular contract law doctrines, selecting some that make a special contribution to the goal of minimizing harms resulting from disputes. In section 3, the article advances a qualified normative claim: conflict-minimization should be considered one of contract law's goals, though it would be wrong to make it contract law's sole concern. In contract law, as elsewhere, the collective desire to maintain harmony must sometimes yield to other important societal aims. But any tension between preserving peace and doing justice is less acute than it may seem at first glance. In particular, because peaceful dispute processes typically serve the parties' joint interests, it is typically fair to say that they have implicitly agreed — or, more realistically, that they would have agreed — to an approach to contractual adjudication that leads to more harmonious relationships and less wasteful disputes.

\footnotetext{
${ }^{17}$ Throughout this article, I will tend to speak of minimizing or managing conflicts, rather than resolving them. For a similar usage in the historical literature, arguing for a shift in historical research from 'conflict resolution' to 'conflict management', see Alain Wijffels, 'Introduction: Commercial Quarrels - and How (Not) to Handle Them' (2017) 32 Continuity and Change 1, 6.

${ }^{18}$ Ian Macneil, 'Values in Contract: Internal and External' (1983) 78 Northwestern U L Rev 340, 353.
} 


\section{Contract Law's Contribution to Conflict-Minimization}

Does contract law have the effect of minimizing conflict? By 'contract law', for the moment, ${ }^{19}$ I mean the option for a party to seek redress for complaints against the other party, before a neutral third party with the authority to make binding decisions, ultimately backed by the coercive power of the state (including via arbitration). ${ }^{20}$ The aim of this section is to show that the involvement, or potential involvement, of an independent and powerful thirdparty adjudicator helps to minimize conflict over economic exchange in at least three ways. First, the possibility of being made accountable before a third party helps to secure compliance with perceived norms of behaviour in economic exchange, thereby stopping disputes from arising in the first place. Second, if a dispute does arise, the presence of contract law channels the dispute towards calmer modes of disputation, as opposed to more harmful or wasteful forms of conflict. Third, both before and after disputes arise, the prospect of a review of the parties' positions by a neutral third party tends to bring the parties' viewpoints closer together, nudging the parties towards agreed solutions to problems that arise during the performance of their agreements.

To be sure, invoking the legal system is just one of a range of possible ways to respond to disputes. Law's impact on behaviour, including contractual behaviour, is sometimes overstated..$^{21}$ As a colossal literature in economics, anthropology, and sociology shows, in

\footnotetext{
${ }^{19}$ I will say more about what a body of contract law devoted to conflict-minimization should look like in section 2 below.

${ }^{20}$ At least, I mean to include arbitration in circumstances where the state courts will enforce the arbitration award. The empirical literature contains many discussions of what we might call borderline cases between contract law and informal norms, such as private arbitration conducted by trade associations. Eg Lisa Bernstein, 'Opting Out of the Legal System: Extralegal Contractual Relations in the Diamond Industry' (1992) 21 J of Legal Studies 115.

${ }^{21}$ Macaulay's classic study of Wisconsin manufacturers and distributors showed that contract law is often marginal to economic exchange. Stewart Macaulay, 'Non-contractual Relations in Business: A Preliminary Study' (1963) 29 American Sociological Rev 55. At the same time, Macaulay did not conclude that contract law had no effect on behaviour - in fact, he has devoted a great deal of effort to figuring out what contract law's effects are. See, for example, the articles cited in notes 85 and 179 below.
} 
small groups, interactions can be, and often have been, governed peacefully by informal norms. ${ }^{22}$ People who share membership in such groups often rely on interpersonal trust and reputation to induce compliance with norms, and informal norms about how to respond to claimed wrongdoing can limit the risks of escalating retaliation. ${ }^{23}$ Still, interpersonal trust, informal norms, and reputational sanctions are much less effective in interactions between relative strangers. As some of the examples discussed below show, strangers will sometimes see fit to engage in economic exchange even though they do not share membership in a closeknit community. In such cases, contract law is more likely to be significant in helping to contain their disputes. For these reasons, economic historians studying the emergence of state-sponsored adjudication of commercial disputes tend to conclude that 'whatever informal modalities of conflict resolution and management may have coexisted within a polity, some degree of a formal justice system was needed in order to back up or supplement the more informal modalities'. ${ }^{24}$

One way to help uncover contract law's dispute-reduction value is to consider the counterfactual: what happens without contract law? Without contract law, contracts, in the economic sense of the term, are still made. ${ }^{25}$ People still make agreements to engage in economic exchange with an element of future performance, thereby exposing one or both parties to the risk of opportunistic behaviour. But, unless they wish to rely solely on the good motives of those with whom they deal, parties need to find alternative mechanisms for

\footnotetext{
${ }^{22}$ See Avner Greif, 'Reputation and Coalitions in Medieval Trade: Evidence on the Maghribi Traders' (1989) 49 J of Economic History 857; Robert C Ellickson, Order Without Law: How Neighbors Settle Disputes (Harvard UP 1994).

${ }^{23}$ Ellickson (n 22) 253: 'In Shasta County, feuds are rare because remedial norms strictly regulate self-help by calling for punishment of persons who respond with excessive force.'

${ }^{24}$ Wijffels (n 17) 4.

${ }^{25}$ For a discussion of the various meanings of 'contract', see Karl Llewellyn, 'What Price Contract? An Essay in Perspective' (1931) 40 Yale LJ 704, 707-08. On one meaning of the word, contracts are agreements to engage in economic exchange 'irrespective of their legal consequences-irrespective indeed of whether they have legal consequences'. ibid 708. Compare Joseph Raz, 'Promises in Morality and Law' (1982) 95 Harv L Rev 916, 917 fn 4 (adopting 'the convention of regarding contracts as legally binding agreements').
} 
decreasing the likelihood of misconduct, and thus, for responding to disputes when the parties cannot agree on the proper response to an allegation of wrongdoing. These mechanisms are frequently less effective for the purpose of minimizing conflict, and may even result in violence, as I show in section A below. But, to be clear: violence is only the most extreme kind of negative consequence of disputes, and it will often be a remote possibility. For that reason, I will proceed in section B to consider subtler, and often more practically significant, instances of negative consequences arising from disputes, consequences that having contract law also helps to minimize.

\section{A. Extreme Cases: Violent Disputes}

The idea that third-party adjudication is more peaceful than other forms of dispute-resolution is far from unique to contract law. Legal scholars trying to say something profound about the purpose of law as a whole often commend litigation as a superior alternative to violent selfhelp. ${ }^{26}$ Access to courts is widely understood as 'necessary to civil society because in the event that individuals cannot resolve their disputes on their own, they may resort to violence'. ${ }^{27}$ The idea that state-sponsored adjudication is a better alternative to the private use of force is also commonplace in political philosophy and legal theory. To take a famous example, H.L.A. Hart made the idea an important part of the famous fable he told to illustrate the distinctive features of legal systems. ${ }^{28}$ Hart first posited a 'pre-legal' society without legislators, courts, or other officials, governed only by customary social rules. One of the

\footnotetext{
${ }^{26}$ To take a representative quotation in a long-running genre: 'The first impulse of a rudimentary soul is to do justice by his own hand. Only at the cost of mighty historical efforts has it been possible to supplant in the human soul the idea of self-obtained justice by the idea of justice entrusted to authorities'. Eduardo J Couture, 'The Nature of the Judicial Process' (1950) 25 Tulane L Rev 1, 7. See also Michael Bayles, 'Principles for Legal Procedure' (1986) 5 Law and Philosophy 33, 57 (legal resolution of disputes is 'preferable to blood feuds, rampant crime and violence, and so on').

${ }^{27}$ Alexandra Lahav, 'The Roles of Litigation in American Democracy’ (2016) 65 Emory LJ 101, 102.

${ }^{28}$ H.L.A. Hart, The Concept of Law (3rd edn, Clarendon Press 2012) ch 5. See John Gardner, 'Why Law Might Emerge: Hart's Problematic Fable' in Luis Duarte d'Almeida, James Edwards, and Andrea Dolcetti (eds), Reading HLA Hart's The Concept of Law (Hart Publishing 2013).
} 
deficiencies Hart attributed to this pre-legal society was the 'inefficiency' of the diffuse social pressure that enforces customary rules. Hart actually divided this problem into two separate sub-problems. First, rules inevitably give rise to frequent disputes over whether they have been broken in a particular case. Without an arbiter to provide an authoritative answer, disputes over alleged rule-violations are likely to 'continue interminably'. ${ }^{29} \mathrm{~A}$ second problem of inefficiency concerns the administration of sanctions without a special agency empowered to impose them. A customary-rules society would have reason to lament not only 'the waste of time involved in the group's unorganized efforts to catch and punish offenders', but also 'the smouldering vendettas which may result from self-help in the absence of an official monopoly of sanctions' ${ }^{30}$ The remedy for these problems is to supplement customary rules with a 'rule of adjudication', ${ }^{31}$ which confers authority on officials to determine whether there has been a breach of the law in a particular case, and to determine the appropriate sanction for breach.

Legal scholars have also examined the relationship between private violence and particular areas of law. Most obviously, criminal law is often conceptualized as a replacement for a private right to use force in self-defence or, more bleakly, as an attempt to domesticate the human urge for violent retribution. ${ }^{32}$ The area of private law most often characterized as a replacement for interpersonal violence is tort law. ${ }^{33}$ On one view, the real purpose of tort damages for non-pecuniary loss is not to compensate but 'to put the plaintiff

\footnotetext{
${ }^{29}$ Hart (n 28) 93.

30 ibid.

31 ibid 97.

${ }^{32}$ Eg James Q Whitman, 'Between Self-Defense and Vengeance/Between Social Contract and Monopoly of Violence' (2004) 39 Tulsa L Rev 901.

${ }^{33}$ See, eg, Scott Hershovitz, 'Tort as a Substitute for Revenge' in John Oberdiek (ed), Philosophical Foundations of the Law of Torts (OUP 2014); Benjamin C Zipursky, 'Rights, Wrongs, and Recourse in the Law of Torts' (1998) 51 Vanderbilt L Rev 1, 85; John CP Goldberg, 'The Constitutional Status of Tort Law: Due Process and the Right to a Law for the Redress of Wrongs' (2005) 115 Yale LJ 524, 602.
} 
in possession of a sum of money which in the court's judgement ought to be enough to satisfy his vindictive feelings against the wrongdoer'. ${ }^{34}$ Tort law has been defended against its critics on the ground that it staves off vengeance: 'it is preferable to pursue a wrong-doer with a writ rather than with a rifle' ${ }^{35}$ But is the problem Hart identified—of smouldering vendettas that continue interminably—relevant to contract disputes?

Historical examples suggest that where parties to economic exchange lack a formal thirdparty adjudicator, less salutary dispute resolution mechanisms often arise to fill the gap. ${ }^{36}$ For example, in Old Testament Israel, 'disputes over contract terms were likely to lead to violence and even blood feuds' ${ }^{37}$ In medieval Europe, too, spirals of violent retaliation often emerged from exchange agreements gone wrong. To be sure, studies of medieval commerce have shown that, even without an overarching government with authority to enforce contracts, small networks of traders were sometimes able to use reputational mechanisms to stabilize and facilitate commerce, without resort to bloodshed. ${ }^{38}$ But, then as now, economic exchange did not always take place within tight-knit reputational networks. In medieval Germany, commercial disputes between merchants in different towns often gave rise to lengthy and devastating feuds between their towns. ${ }^{39}$ Until the fifteenth century, "collective reprisals were regarded as legitimate and were frequently practiced' ${ }^{40}$ Disagreement over

\footnotetext{
${ }^{34}$ JM Kelly, 'The Inner Nature of the Tort Action' (1967) 2 Irish Jurist (New Series) 279, 287.

${ }^{35}$ AM Linden, 'Faulty No-Fault: A Critique of the Ontario Law Reform Commission Report on Motor Vehicle Accident Compensation' (1975) 13 Osgoode Hall LJ 448, 457.

${ }^{36}$ John D Calamari and Joseph M Perillo, The Law of Contracts (4th edn, West Publishing 1998) para 1.4: 'Before courts, there was the feud-private vengeance. ... In modern law, where contract law refuses to enter, vengeance and self-help fill the vacuum.'

${ }^{37}$ Geoffrey P Miller, 'Contracts of Genesis' (1993) 22 J of Legal Studies 15.

${ }^{38}$ Greif (n 22).

${ }^{39}$ Oliver Volckart, 'The Economics of Feuding in Late Medieval Germany' (2004) 41 Explorations in Economic History 282.

40 ibid 286.
} 
commercial transactions was one of the most common causes of these feuds. ${ }^{41}$ These feuds were not anarchic; the parties were governed by rules restricting their initiation. But, once the feud was commenced, there were few restrictions on the 'plunder, looting and devastation' one could visit on one's opponent. ${ }^{42}$ In addition to the injuries and property damage occasioned by feuding, a feud disrupted trade between merchants of the two towns otherwise uninvolved in the dispute. Likewise, disputes over economic exchange in eighteenth and nineteenth century Montenegro often gave rise to feuds, ${ }^{43}$ and arguments over contracts sometimes sparked duels in the antebellum south. ${ }^{44}$

In more recent history, a lack of state-provided contract enforcement aids the emergence of 'organized crime'. As Schelling states, 'when the law has no way of enforcing contract, the underworld provides it: a man submits to the prospect of personal violence as the last resort in contract enforcement'. ${ }^{45}$ To take a concrete example: according to the leading account of its emergence and persistence, the Sicilian mafia is an industry that promotes, produces, and sells private protection. ${ }^{46}$ Protection, Diego Gambetta explains, can be a 'genuine commodity and [can] play a crucial role as a lubricant of economic exchange'. ${ }^{47}$ In the wake of feudalism's decline, weak state authorities in Sicily were unable to provide protection, thus creating a demand for the mafia's product. The mafia's customers sought protection against invasions of property rights, and also against breaches of agreements for

\footnotetext{
41 ibid 286-87.

42 ibid 288.

${ }^{43}$ Christopher Boehm, Blood Revenge: The Enactment and Management of Conflict in Montenegro and Other Tribal Societies (University of Pennsylvania Press 1984) 88.

${ }^{44}$ For discussion of an example of a duel sparked by an unpaid promissory note, see Warren F Schwartz, Keith Baxter and David Ryan, 'The Duel: Can These Gentlemen be Acting Efficiently?' (1984) 13 J of Legal Studies 331,352

45 Thomas C Schelling, Choice and Consequence: Perspectives of an Errant Economist (Harvard UP 1984) 168.

${ }^{46}$ Diego Gambetta, The Sicilian Mafia: The Business of Private Protection (Harvard UP 1993).

47 ibid 2.
} 
economic exchange. Thus, mafiosi in the nineteenth century protected buyers and sellers in disputes over sales of horses, ${ }^{48}$ and, in the twentieth century, in disputes over sales of used cars. ${ }^{49}$ Gambetta cites examples of mafiosi settling disputes over construction contracts, ${ }^{50}$ labour contracts, ${ }^{51}$ and contracts for the use of land. ${ }^{52}$ Mafiosi also provided, and continue to provide, debt collection and debt postponement services. ${ }^{53}$ The Sicilian mafia is just one example; scholars have reached similar conclusions about organized crime in Russia ${ }^{54}$ and Japan, ${ }^{55}$ both places where, in different ways, there is a substantial gap between formal rights and their actual enforcement via the legal system.

The mafia originally thrived where contracts were formally enforceable but practically unenforceable because the state legal system was too weak. Violence also often enters the picture where the agreement in question is illegal and hence unenforceable in the courts. One long-standing mafia activity is the enforcement of illegal cartel agreements. ${ }^{56}$ More generally, contemporary black-market commerce, a field in which participants are unable to harness legal protections against fraud or breach of contract, is often linked to systemic violence. According to Goldstein, 'systemic violence arises from the exigencies of working or doing business in an illicit market - a context in which the monetary stakes can be enormous but where the economic actors have no recourse to the legal system to resolve

\footnotetext{
48 ibid $73-74$.

${ }^{49}$ ibid $169-70$.

${ }^{50}$ ibid 170.

${ }^{51}$ ibid 169.

52 ibid 170.

${ }^{53}$ ibid $170-71$.

${ }^{54}$ Federico Varese, The Russian Mafia: Private Protection in a New Market Economy (OUP 2006).

${ }^{55}$ Curtis J Milhaupt and Mark D West, Economic Organizations and Corporate Governance in Japan (OUP 2004) ch 8.

${ }^{56}$ Oriana Bandiera, 'Land Reform, the Market for Protection, and the Origins of the Sicilian Mafia: Theory and Evidence' (2003) 19 J of Law, Economics, and Organization 218, 220.
} 
disputes' ${ }^{57}$ Research into illegal drug dealers explains that dealers need to establish a reputation for violence. As buyers, they need to avoid being supplied with poor quality product, and as sellers they need protection against failure to pay debts. So 'violence substitutes for legal contract enforcement in the illegal drug market'. ${ }^{58}$ Elijah Anderson, writing about street-level crack dealers in the United States, explains how violence occurs even though the perpetrators do not particularly want to use it. ${ }^{59}$ Without any prospect of adjudication by a neutral third party, business arguments over drugs 'are frequently settled on the spot, typically on the basis of arbitrary considerations, unfounded assumptions, or outright lies'. ${ }^{60}$ More troublingly, a sort of 'code of the street' emerges to regulate and justify the use of violence. ${ }^{61}$ To maintain 'respect', one must respond swiftly and harshly to signs of disrespect. In drugs transactions, this means that misunderstandings or unpaid debts frequently result in violent reprisals; the logic of the street is unforgiving. ${ }^{6}$

\footnotetext{
${ }^{57}$ Paul J Goldstein, 'The Drugs/Violence Nexus: A Tripartite Conceptual Framework' (1985) 14 J of Drug Issues 493. For a useful review of scholarly hypotheses about the relationship between drug markets and violence, see Graham C Ousey and Matthew R Lee, 'Investigating the Connections Between Race, Illicit Drug Markets, and Lethal Violence, 1984-1997' (2004) 41 J of Research in Crime and Delinquency 352.

${ }^{58}$ US Department of Justice, Bureau of Justice Statistics, Drugs, Crime, and the Justice System (U.S. Government Printing Office 1992).

${ }^{59}$ Elijah Anderson, The Code of the Street: Decency, Violence, and the Moral Life of the Inner City (WW Norton \& Co 1999). See also Philippe Bourgois, In Search of Respect: Selling Crack in El Barrio (2nd edn, CUP 2003).

${ }^{60}$ Anderson (n 59) 117.

${ }^{61}$ As critics have pointed out, however, it may be misleading to describe these patterns of behaviour as a 'code'. Loïc Wacquant, 'Scrutinizing the Street: Poverty, Morality, and the Pitfalls of Urban Ethnography' (2002) 107 Am J of Sociology 1468, 1490-93.

${ }^{62}$ Anderson (n 59) 116. Illicit drug-dealing is not always drenched in quite so much violence. One study claims to show that drug dealers in the suburban United States abide instead by a less violent 'code of the suburb', whereby dealers typically respond to suspected contractual misconduct with negotiation, avoidance, and tolerance. Still, suburban dealers do sometimes seek to obtain vengeance; they tend to do so instead 'via "sneaky" methods such as retaliatory rip-offs, unseen thefts (e.g., burglary), and vandalism'. Scott Jacques and Richard Wright, 'The Code of the Suburb and Drug Dealing' in The Oxford Handbook of Criminological Theory (OUP 2012).
} 
Where the law refuses to enforce gambling debts, these, too are often a fertile source of disorderly contract disputes. ${ }^{64}$ For example, millions of people from mainland China visit Macau each year. Gambling debts are legally unenforceable in China. That does not mean that gambling debts incurred in Macau by Chinese gamblers go unenforced. ${ }^{65}$ One casino investor recently explained, euphemistically, that debts could be collected by 'following the guy until he pays ... If the guy has 10 guys, you need to have 50 guys following them. So that's just part of that business ... If you can't enforce it in the legal system, what can you do?'66 The U.K. moved to an open, regulated gambling industry in part to deal with a problem of violent enforcement of gambling debts, ${ }^{67}$ and has now made gambling contracts legally enforceable, partly with the aim of keeping gambling crime-free. ${ }^{68}$

Historians and social scientists differ among themselves as to how to understand violent forms of dispute-resolution. Feuding, for example, may flow from an aspect of human psychology that cannot be explained in rational-choice terms: a deep-rooted emotional compulsion or a desire for honour in the face of a perceived slight. ${ }^{69}$ But some economic historians have interpreted feuding over contracts as rational and, on the whole, socially beneficial, arguing that it was a calculated mechanism for deterring wrongdoing and enhancing the credibility of promises, and, in turn, facilitating trade even without overarching authorities. ${ }^{70}$ Nevertheless, all seem to agree that feuding is, at most, a second-best solution

\footnotetext{
64 'Purported Enforcer for Naples Betting Ring Takes Plea Deal' Naples Daily News (Naples, 8 May 2015): 'On undercover surveillance tapes, [an illegal bookie] bragged about having a network of enforcers across the country, including Ross, calling him a Hannibal Lecter-type who "will bite your face off".'

${ }^{65}$ See Federico Varese, Mafias on the Move: How Organized Crime Conquers New Territory (Princeton UP 2012) 166-69.

${ }^{66}$ James Ball, Harry Davies, Lowell Bergman, Matt Isaacs, and Simon Marks, 'How China’s Macau Crackdown Threatens Big US Casino Moguls' The Guardian (London, 23 April 2015).

${ }^{67}$ Roy Light, 'The Gambling Act 2005: Regulatory Containment and Market Control' (2007) 70 MLR 626.

${ }^{68}$ Gambling Act 2005, s 335(1).

${ }^{69}$ Jon Elster, 'Norms of Revenge' (1990) 100 Ethics 862.

${ }^{70}$ Volckart (n 39).
} 
that should give way if more peaceful mechanisms are available and effective. Similarly, even if the emergence of a mafia as an enforcement mechanism has its pluses, it also brings with it unfortunate problems. To provide protection a mafioso must provoke fear in others; to provoke fear he must engage in otherwise gratuitous acts of violence and to react with extreme force if anyone challenges his honour. The use of violence to enforce contracts, as well as being harmful in itself, also supports and funds people with a tendency to use violence to get their way, a tendency that may spill over into other activities and areas of life.

Informal institutions - unwritten rules of social behaviour - do most of the work of containing disputes over economic exchange, but they tend to suffer from weaknesses that restrict their ability to control violence: in addition to being biased towards more powerful interests, they may be unable to 'elicit private information, resulting in costly negotiations' and 'without central enforcement, they may produce bargains that are difficult to keep'. ${ }^{71}$ So it is no surprise that scholars of contemporary international development take the need for effective formal dispute-resolution systems as a prerequisite for economic advance.

Otherwise, '[e]very ... business deal or loan risks giving rise to a costly disagreement or dispute, some of which turn violent' ${ }^{72}$

Law can reduce or eliminate these violent responses to disputes over economic exchange by changing the incentives and attitudes of actors who would otherwise be compelled or tempted to invoke them. The most obvious way that the state can reduce the incidence of escalating cycles of vengeance is to insist on a monopoly of the legitimate use of violence, by criminalizing violent behaviour. The mere enactment of criminal prohibitions, however, does not automatically stop aggrieved parties from taking the law into their own hands unless the

\footnotetext{
${ }^{71}$ Christopher Blattman, Alexandra C Hartman, and Robert A Blair, 'How to Promote Order and Property Rights under Weak Rule of Law? An Experiment in Changing Dispute Resolution Behavior through Community Education' (2014) 108 American Political Science Rev 100, 100.

72 ibid.
} 
prohibition on violence is actually enforced. Criminal prosecutions cost money, and the relevant authorities may simply have other priorities.

So the state may further reduce the incentive to use violence by providing a calmer, more measured outlet for grievances in the courts. Some early forms of resolving disputes in the courts, like trial by battle, can be seen as a transitional stage between extra-legal violence and non-violent litigation. ${ }^{73}$ The origins of the common law lie in royal attempts to manage violent feuding ${ }^{74}$; as a first step, early legal systems aimed to regulate and control vengeance rather than to replace it. Likewise, so-called '[p]rimitive contract law ... is affected strongly by elements of vengeance'. ${ }^{76}$ But modern contract law, as we will see below, aims to supplant rather than to satisfy the desire for revenge.

\section{B. Beyond Violence}

Violence is an unlikely outcome in many contemporary contractual settings: to large extent, criminal prohibitions and social norms do restrain violence. But violence is not the only kind of regrettable response to a dispute that contract law can help to forestall. A party to a dispute may have to expend time and energy on wrangling with her opponent and on trying to convince others that she is in the right. Bitterness, or a perceived need to maintain respect, may lead the parties to badmouth and defame each other, thereby harming not only the parties but also the broader market interest in accurate information. ${ }^{78}$ Most importantly, perhaps, parties who anticipate an acrimonious conflict may leap too quickly to the easiest self-help remedy: refusing to deal any further with the other party. An excessively

\footnotetext{
${ }^{73}$ For a recent analysis, see Peter T Leeson, 'Trial by Battle' (2011) 3 J of Legal Analysis 341.

${ }^{74}$ Paul R Hyams, Rancor and Reconciliation in Medieval England (Cornell University Press 2003). Trial by battle, for example, rarely resulted in death because of rules limiting the weapons that champions could use. Leeson (n 73) 365.

${ }^{76}$ Llewellyn (n 25) 737.

${ }^{78}$ Contract law will not completely eliminate this kind of behaviour. For a recent example of a defamation suit after the breakdown of a contractual relationship, see Flymenow Ltd v Quick Air Jet Charter GmbH [2016] EWHC 3197 (QB).
} 
pugnacious approach to disputes, then, may lead the parties to lose the opportunity for continued mutually beneficial exchange. The more bitter the dispute, the lower the possibility that the parties will maintain or resume their business relationship.

As noted above, one way that having contract law can help to reduce the harms arising from disputes is to prevent disputes from arising in the first place. The goal of conflictminimization is thus not purely 'backward-looking'; it cuts across Patrick Atiyah's distinction between two kinds of social ends that the judicial process might be designed to serve. ${ }^{79}$ Atiyah distinguishes between, first, encouraging the citizenry to comply with socially desired standards of behaviour and, second, providing machinery for the settlement of disputes by fair and peaceful means. The goal of conflict-minimization is mostly obviously related to the second of these purposes, which responds to disputes after they have arisen. But by providing incentives to refrain from behaviour that is likely to give rise to a dispute, contract law can also prevent some disputes from arising at all.

Still, some level of disputing is inevitable. How does contract law help to minimize the harms resulting from disputes after they have arisen? In part, it does so by channelling the parties' emotional responses to conflict into the 'cold courts' that adjudicate breach of contract claims. ${ }^{80}$ It may seem paradoxical to claim that the prospect of litigation and the involvement of lawyers could reduce the time and effort that contracting parties spend fighting with each other. Lawyers might have self-interested incentives to stir up rather than to end conflicts, and are often accused (especially in the United States) of taking an excessively adversarial approach to disputes. ${ }^{81}$ One of Stewart Macaulay's interviewees, for

\footnotetext{
${ }^{79}$ PS Atiyah, 'Contracts, Promises, and the Law of Obligations' in Essays on Contract (Revised edn, OUP 1990) 14-15.

${ }^{80}$ Balfour v Balfour [1919] 2 KB 571 (CA).

${ }^{81}$ Eg Robert A Kagan, 'Do Lawyers Cause Adversarial Legalism? A Preliminary Inquiry' (1994) 19 Law and Social Inquiry 1.
} 
example, said that lawyers 'just do not understand the give-and-take necessary in business' ${ }^{82}$ Moreover, according to David Campbell, contract law in its current form suffers from an inflexible 'vindication mentality' which 'casts its pall over post-breach negotiations where reference to the contract takes the form of exchanges of surrenders of adversarially asserted claims' ${ }^{83}$ It is hard to disagree with Campbell that contract law and the legal profession might be better designed to minimize conflict; but the question for the moment is just whether it makes some contribution to that aim.

And indeed, there is ample evidence that, even in its current form, contract law helps to manage conflict. This may be most obvious when one looks to the lawyers who help to draft and negotiate contracts. Lawyers often convey the norms of a commercial community to their clients, helping to prevent disputes from arising. ${ }^{84}$ Moreover, once a dispute deteriorates to the point where litigation is a possibility, the prospect of litigation or arbitration typically requires the parties to turn the matter over to lawyers. Legal representatives bring objectivity to a dispute, with the capacity to calm it by explaining to clients the weaknesses of their position. Even when a dispute is in the hands of in-house lawyers, it is out of the hands of those who negotiated and attempted to perform the contract. As Macaulay points out, the shift to lawyers makes the dispute 'less of a question of ego and responsibility for making what has turned out to be a bad bargain' ${ }^{85}$ Moreover, as repeat players in legal disputes, lawyers often have a greater incentive than their clients to conduct disputes in a more

\footnotetext{
${ }^{82}$ Macaulay (n 21) 61.

${ }^{83}$ Campbell (n 12) 471. See also Collins (n 12) 321-22: 'The assertions of entitlement and correlative obligation which fuel the legal process of litigation and adjudication tend to exacerbate the conflict between the parties.'

${ }^{84}$ Mark C Suchman and Mia L Cahill, 'The Hired Gun as Facilitator: Lawyers and the Suppression of Disputes in Silicon Valley’ (1996) 21 Law and Social Inquiry 679.

${ }^{85}$ Stewart Macaulay, 'Renegotiation and Settlements: Dr. Pangloss's Notes on the Margins of David Campbell's Papers' (2007) 29 Cardozo L Rev 261, 284.
} 
civilized manner. ${ }^{86}$ Further, because the legal system usually moves slowly, the possibility of a lawsuit requires one who considers herself a victim of wrongdoing to wait a little; the passage of time gives her the opportunity to reassess the extent of her loss and the other party's blameworthiness, and to transcend her initial anger. ${ }^{87}$ The litigation system bureaucratizes disputes by requiring the disputants to seek advice from non-disputants, and by requiring the dispute to be conducted in the technical, even bland, discourse of the law.

To a large extent, contract law encourages the minimization of conflict by encouraging the parties to lay down their arms and reach agreement. ${ }^{88}$ The prospect of having their arguments scrutinized by a neutral third party often serves as a 'reality check'. It forces the parties to reflect more honestly on their own self-serving positions, inducing compromise. Again, the goal of conflict minimization fits better with the reality of contract litigation, the vast majority of which ends in a negotiated settlement rather than with adjudication, so much so that scholars of dispute resolution have suggested we refer to 'litigotiation' rather than litigation. ${ }^{89}$ For Collins, indeed, mutual agreement is the only way to bring about a peaceful resolution..$^{90}$

While settlement of contractual disputes is the paradigmatic conflict-ending event, however, it is not the only one. As a last resort, adjudication of a dispute by a third party can

\footnotetext{
${ }^{86}$ Ronald J Gilson and Robert H Mnookin, 'Disputing Through Agents: Cooperation and Conflict between Lawyers in Litigation’ (1994) 94 Colum L Rev 509.

${ }^{87}$ For evidence supporting a similar claim in the case of tort litigation, see John Bronsteen, Christopher Buccafusco, and Jonathan S Masur, 'Hedonic Adaptation and the Settlement of Civil Lawsuits' (2008) 108 Colum L Rev 1516. The authors contend that personal injury victims tend at first to overestimate the extent of their injuries, and that a benefit of litigation's slow speed is that it gives time for victims to adapt and hence accept settlement offers.

${ }^{88}$ See Steven Shavell, Foundations of Economic Analysis of Law (Harvard UP 2004) ch 17, § 4.4: 'an important justification for society's having established the legal apparatus for the holding of trials is, paradoxically, not to have trials occur. Rather, it is to provide victims with the threat necessary to induce settlements'.

${ }^{89}$ Marc Galanter, 'Worlds of Deals: Using Negotiation to Teach about Legal Process' (1984) 34 J Leg Ed 268. See also Simon Roberts, “'Listing Concentrates the Mind”: The English Civil Court as an Arena for Structured Negotiation' (2009) 29 OJLS 457.

${ }^{90}$ Collins (n 12) 322: 'a peaceful resolution can occur only by agreement between the parties, so the objective of regulation must be to establish mechanisms designed to facilitate an agreement or settlement'.
} 
effectively put an end to a dispute: the losing party accepts an adverse decision or, at least, is willing to concede defeat. A decision reached via a fair procedure is more likely to acquire legitimacy and, thus, to receive compliance. ${ }^{92}$ The effectiveness of a contract law regime at solving conflict, then, will depend in part on its perceived legitimacy among those who receive unfavourable decisions.

\section{Conflict-Minimization and the Design of Contract Law}

The goal of minimizing the negative consequences of disputes is not just a reason to have contract law in general; it also bears on the countless choices that a legal system has to make when deciding how to design and implement a system of contract law. Some of the most important choices concern the rules and practices of civil procedure. Depending on the content of these rules and practices, it is possible for litigation to exacerbate rather than ameliorate conflict. Prompted by this concern, the conflict-minimization imperative has plainly influenced English civil procedure in recent years. The Woolf Reforms, for example, were motivated by a sense that litigation was so adversarial as to be uncomfortably similar to warfare. ${ }^{93}$ Some of these developments in litigation practice are not unique to contract law: judges and parties, for example, are now required to consider ADR to promote an agreed settlement as an alternative to continued litigation. ${ }^{94}$ Some developments in procedural law are, however, specific to contract disputes. English courts have shown their willingness to enforce contractual clauses requiring the parties to mediate before commencing litigation. ${ }^{95}$

\footnotetext{
92 See Tom R Tyler, Why People Obey the Law (Yale UP, 1990).

93 'Without effective judicial control ... the adversarial process is likely to encourage an adversarial culture and to degenerate into an environment in which the litigation process is too often seen as a battlefield where no rules apply'. Lord Harry Woolf, 'Civil Justice in the United Kingdom’ (1997) 45 Am J Comp L 709, 710.

${ }^{94}$ For more detail on the ways that the English Civil Procedure Rules encourage the parties to settle their disputes both before and after the commencement of proceedings, see Linda Mulcahy, 'The Collective Interest in Private Dispute Resolution' (2013) 33 OJLS 59, 68-69.

${ }^{95}$ Cable \& Wireless plc v IBM [2002] EWHC 2059 (Comm).
} 
And the policy of deference to arbitration, a process used almost exclusively for contractual disputes, is based on the claim that arbitration is a faster, cheaper, and less wasteful way of conducting disputes. ${ }^{96}$

But what of the substantive law of contract? How might it be affected by the disputereduction goal? In this section, I will canvass some particular doctrines of contract law, with a focus on English law, to illustrate the role of conflict-minimization. The claim is not that English law is perfectly adapted to conflict-minimization. The claim, instead, that some of its doctrines make a significant contribution to this aim.

To begin with, as a general matter, the goal of conflict-minimization tends to favour freedom of contract. One of the most important reasons to make contracts is to prevent disputes from arising by agreeing on what the parties' obligations will be in certain contingencies. ${ }^{97}$ To encourage and support this practice, courts should typically enforce contracts as agreed. Further, where its meaning is unclear, they should usually interpret the text of written contracts in such a way as to minimize conflict. ${ }^{98}$ Moreover, there is more to contract law than interpreting and enforcing express terms of contracts. Many of the doctrines discussed below involve gap-filling by the courts where the parties have made no agreement on the contested matter; that gap-filling exercise is influenced by the aim of reducing conflict. In exceptional circumstances, legislatures and courts have decided to second-guess

\footnotetext{
96 This argument for arbitration, however, is now considered factually dubious by many. 'It may then be said that the arbitration provides a more efficient and cheaper option than long, protracted litigation, that it has procedural advantages, such as narrower rules on disclosure than the courts. Such claims would not, I think, stand up against detailed scrutiny today'. Lord Thomas of Cwmgiedd, 'Developing Commercial Law through the Courts: Rebalancing the Relationship between the Courts and Arbitration' (The BAILII Lecture, London, 9 Mar 2016), <https://www.judiciary.gov.uk/wp-content/uploads/2016/03/lcj-speech-bailli-lecture-20160309.pdf> accessed 8 June 2017, [43].

${ }^{97}$ Ian R Macneil, 'A Primer of Contract Planning' (1974) 48 S Cal L Rev 627.

${ }^{98}$ Conflict-minimization is thus as an aspect of the 'commercial common sense' that informs the interpretation of written contracts. See Rainy Sky SA v Kookmin Bank [2011] UKSC 50 [40], [2011] 1 WLR 2900, 2914.
} 
the parties' choice of contract terms where those terms are likely to lead to an unacceptable degree of conflict. ${ }^{99}$

\section{A. Default Remedies for Breach}

Consider, first, contract law's general commitment to compensatory damages as the proper response to breach of contract. This commitment has two aspects: a preference for damages over specific enforcement of non-monetary obligations, and a commitment to compensation for loss rather than some higher amount of damages. From the perspective of theories of contract law based on promissory morality, each of these features has proved troublesome. ${ }^{100}$ From a conflict-minimization perspective, however, each of these features is more readily understandable.

First, English law is famously reluctant to require actual performance of non-monetary obligations. ${ }^{101}$ The law is not universally hostile to specific performance; instead, it allows judges to make decisions about when the remedy is appropriate. One important factor counting against specific enforcement is the need to help put an end to a dispute rather than prolong it. This factor looms large in contracts for personal services or for the continuing provision of services, where the 'degree of the daily impact of person upon person' is high. ${ }^{102}$ This motivation is explicit in the leading case on specific performance, Co-operative Insurance v. Argyll. ${ }^{103}$ The case concerned a contractual obligation to keep a shop open, an

\footnotetext{
${ }^{99}$ See sections 2.B and 2.C below.

${ }^{100}$ See Shiffrin (n 10). Schwartz and Markovits, however, have argued that the remedy of expectation damages comports with the morality of promising: on their view, a contractual promise is typically a promise to perform or to pay expectation damages. Alan Schwartz and Daniel Markovits, 'The Myth of Efficient Breach: New Defenses of the Expectation Interest' (2011) 97 Virginia L Rev 1939. For Shiffrin's response, see Seana Valentine Shiffrin, 'Must I Mean What You Think I Should Have Said?' (2012) 98 Virginia L Rev 159.

${ }^{101}$ By contrast, the routine availability of specific enforcement of monetary obligations through the action for an agreed sum does not raise the same kinds of conflict-minimization concerns. Distinct problems with debtcollection, however, are discussed in sections 2.C and 2.D below.

${ }^{102}$ CH Giles \& Co Ltd v Morris [1972] 1 WLR 307 (Ch) 318.

${ }^{103}$ Co-op Insurance Society v Argyll Stores [1999] AC 1 (HL).
} 
obligation the House of Lords found inappropriate for specific performance. In justifying this conclusion, Lord Hoffmann relied first on the standard law-and-economics argument that requiring a defendant to carry on a business at a loss is inefficient. ${ }^{104}$ But he also noted that such an order 'yokes the parties together in a continuing hostile relationship' ${ }^{105}$ If a court makes an order for specific performance in such circumstances, it 'prolongs the battle' between parties whose relationship has already deteriorated to a point where they are in court. ${ }^{106}$ If a defendant is required to continue running a business, "its conduct becomes the subject of a flow of complaints, solicitors' letters and affidavits'. ${ }^{107}$ That would be wasteful for both parties and for the legal system. 'An award of damages', by contrast 'brings the litigation to an end. The defendant pays damages, the forensic link between them is severed, they go their separate ways and the wounds of conflict can heal'. ${ }^{108}$

The conflict-minimization explanation of the courts' reluctance to order the continued performance of services is more convincing than the much-criticized idea that specific performance would require the court's 'constant supervision'. ${ }^{109}$ And it recurs in the case law. In another case, a court refused to enjoin termination of on the ground that awarding such relief would 'require two parties who have fallen out with each other and one of whom has lost confidence in the other to continue to work together'. ${ }^{110}$ In another still, a court refused to order a fee-paying school to reinstate an expelled student, citing the 'difficulties inherent

\footnotetext{
${ }^{104}$ I bracket the considerable debate among law-and-economics scholars as to whether and when specific performance might be a more 'efficient' remedy than damages. See Alan Schwartz, 'The Case for Specific Performance' (1979) 89 Yale LJ 271; Thomas S Ulen, 'The Efficiency of Specific Performance: Toward a Unified Theory of Contract Remedies' (1984) 83 Mich L Rev 341.

${ }^{105}$ Co-op (n 103) 16.

106 ibid 16.

107 ibid.

108 ibid.

${ }^{109}$ Ryan v Mutual Tontine Westminster Chambers Association [1893] 1 Ch 11 (CA). For judicial scepticism about the 'constant supervision' objection see, for example, CH Giles \& Co Ltd v Morris [1972] 1 WLR 307 (Ch) 318; Shiloh Spinners Ltd v Harding [1973] AC 691 (HL) 724

${ }^{110}$ Ericsson AB v Eads Defence \& Security Systems Ltd [2009] EWHC 2598 (TCC) [47].
} 
in the breakdown of trust and the undesirability of requiring parties to coexist in a pastoral or educational relationship'. ${ }^{111}$ In particular, conflict-minimization provides a significant part of the justification for the law's refusal to order specific performance of an employee's obligation to work, long enshrined in statute. ${ }^{112}$ A recent Supreme Court opinion notes 'the sensitivity which the common law had always had about any intervention by a court which might force the parties to continue in a relationship which has been described as "at once inter-dependent and oppositional"”. ${ }^{113}$

A conflict-management approach also fits well with contract law's general commitment to compensation for loss as the measure of damages for breach. Contract law does not give effect to a vindictive desire to inflict suffering on a contract-breaker; it is not well suited to achieving retaliation for breach. ${ }^{114}$ Certainly, those who bring contract claims may be motivated by the desire to take vengeance. ${ }^{115}$ The remedies the law offers, however, do not match that motivation. ${ }^{116}$ Punitive or exemplary damages are not awarded for breach of contract in English law; ${ }^{117}$ even awards of damages that strip the contract-breaker of the

\footnotetext{
${ }^{111} R$ v Incorporated Froebel Institute [1999] ELR 488 (QB) 493.

112 The most recent version of this prohibition is section 236 of the Trade Union and Labour Relations (Consolidation) Act 1992.

${ }^{113}$ Geys v Société Générale, London Branch [2012] UKSC 63 [119]; [2013] 1 AC 523, quoting William Cornish, Oxford History of the Laws of England, vol XIII (OUP 2010) 623.
}

${ }^{114}$ Compare the position of Oman (n 7); Oman (n 14) ch 6. There is some affinity between my argument and Oman's, but, as explained in the text, I do not agree that retaliation constitutes contract law's 'basic structure'. ibid 551.

${ }^{115}$ Marc Galanter and David Luban, 'Poetic Justice: Punitive Damages and Legal Pluralism' (1993) 42 American U L Rev 1393, 1406: 'Ordinary compensatory damages may be pursued for purposes of vengeance, retribution, or vindication'.

${ }^{116}$ See Whitman (n 32) 904: 'if parties litigate in order to get vengeance or satisfaction, American law does not generally respond by offering remedies tailored to those desires'.

${ }^{117}$ Addis v Gramophone Co Ltd [1909] AC 488 (HL). For more recent authority, see Crawfordsburn Inn v Graham [2013] NIQB 79. 
profits of breach—a remedy that may also be inspired by vindictive motives ${ }^{118}$ —are extremely rare. ${ }^{119}$

At first sight, it might appear that, to provide an effective substitute for extra-legal vengeance, contract law would need itself to offer victims a form of retaliation, though one that is 'limited and civilized through litigation' ${ }^{120}$ And in some social conditions, where the law's authority is weak, its best hope will be to provide a less harmful form of revenge. As we have already seen, the common law's earliest responses to wrongdoing sought only to regulate and control vengeance. ${ }^{121}$ Contemporary contract law is more ambitious. In providing an alternative to vengeful extra-legal behaviour, courts hope also to avoid becoming instruments of vengeance. If a party trusts that a neutral decision-maker will make an unbiased and authoritative decision concerning its claim to redress, much of the reason to seek revenge is removed. Rather than inflicting retaliation for breach, contract law aims to make vengeance unnecessary.

\section{B. Agreed Remedies}

What if the parties seek to vary the law's default rules by stipulating a different remedy for breach? The conflict-minimization goal generally supports the freedom of parties to specify the quantum of damages for breach. If the parties can agree in advance, they will greatly save on disputes over the numbers later. Another valid purpose, in conflict-management terms, is to prevent breach. If a penalty is so stiff as to provide a deterrent against breach, the parties may be spared a dispute: if there is no breach of contract, there will, perforce, be no dispute

\footnotetext{
${ }^{118}$ Emily Sherwin, 'Compensation and Revenge' 40 San Diego L Rev 1387, 1403: 'The claimant [seeking a profit-stripping remedy] desires not only to be reimbursed, but also to eliminate the wrongdoer's profits-a desire that is essentially vindictive'.

${ }^{119}$ See Attorney General v Blake [2000] UKHL 45, [2001] 1 AC 268.

${ }^{120}$ Oman (n 7) 543.

${ }^{121}$ Part 1.A above.
} 
over the consequences of that breach. But even the otherwise-powerful principle of freedom of contract must sometimes give way to the interest in peaceful dispute resolution. The law has long limited the enforceability of agreements for supra-compensatory damage measures, even between commercial parties. While many commentators have found this limitation hard to explain, ${ }^{133}$ contractual clauses providing for punishment for breach risk exacerbating conflict, entailing unjustified harms to the parties and to others. ${ }^{134}$ As Seana Shiffrin has argued, the courts do not, and should not, cede total control over contractual remedies to the parties. In selecting remedies, the parties may not pay sufficient heed to the public purposes of punishment. These purposes 'include an interest in replacing vengeance and private retaliation with deliberative and impartial remediation'. ${ }^{135}$

Hence, a conflict-minimization perspective helps to support the U.K. Supreme Court's recent decision to reaffirm, in modified form, the rule against penalties. ${ }^{136}$ The rule against penalties is still said to be based on a public policy 'that the courts will not enforce a stipulation for punishment for breach of contract', ${ }^{137}$ and the Court reiterated the idea that ' $[\mathrm{t}]$ he innocent party can have no proper interest in simply punishing the defaulter'. ${ }^{138}$ But it is now clear is that the fact that the primary purpose of a stipulation is deterrence of breach does not make it punishment. ${ }^{139}$ As a result, the meaning of 'punishment' in this context is

\footnotetext{
${ }^{133}$ See, for example, Solene Rowan, 'For the Recognition of Remedial Terms Agreed Inter Partes' (2010) 126 LQR 448.

${ }^{134}$ In The Merchant of Venice, Shylock's determination to enforce Antonio's contractual promise of a pound of flesh, despite being offered a sum thrice the debt it was supposed to secure, was motivated by a desire to take revenge on Antonio (in part for Antonio intervening in Shylock's contractual relations with others). III.i.55-60.

${ }^{135}$ Seana Valentine Shiffrin, 'Remedial Clauses: The Overprivatization of Private Law' (2016) 67 Hastings LJ 407, 423.

${ }^{136}$ Cavendish Square Holding BV v Makdessi [2015] UKSC 67.

137 ibid [243] (Lord Hodge).

138 ibid [32] (Lords Neuberger and Sumption).

${ }^{139}$ Under the previous rule, a damages clause was invalid unless it was a genuine pre-estimate of the victim's loss. Dunlop Pneumatic Tire Co v New Garage Ltd. [1915] AC 79 (HL). Under the new rule, a damages clause need not be a genuine pre-estimate of the victim's loss. A clause may be valid even though its purpose is to
} 
somewhat opaque, ${ }^{140}$ but it seems to mean something like vengeance. Some commentators have suggested that this understanding of the penalties rule will lead to the rule's virtual exclusion from commercial cases, because 'a contractual clause inserted purely to mete out punishment for punishment's sake must be rara avis indeed'. ${ }^{141}$ Still, the retention of the jurisdiction over penalties allows the courts to strike down those clauses whose presence in the contract, however initially motivated, is particularly conducive to conflict and mutual retaliation once a dispute arises.

Similar considerations underpin the (currently undeveloped) law on the enforceability of specific performance clauses. ${ }^{142}$ While the courts should generally accept the parties' prior decision that specific performance should be available, freedom of contract must sometimes yield to the interest in minimizing conflict between the parties. In one of the few judicial discussions of this question, two Court of Appeal judges indicated that the discretion to order specific performance 'cannot be fettered' by the parties' prior agreement; ${ }^{143}$ 'it is not the function of the court to be a rubber stamp'. ${ }^{144}$ One important reason for the courts to retain the discretion to deny specific performance, even when the parties have previously agreed to it, is to put an end to a conflict-ridden contractual relationship.

\section{Self-Help and Repossession}

The goal of conflict minimization affects not only the remedies for breach of contract but also the means of enforcing them. An aggrieved party seeking payment of a debt or

deter breach, but only if the size of the penalty is proportionate to the prospective victim's interest in performance.

${ }^{140}$ See Andrew Summers, 'Unresolved Questions in the Law of Penalties' [2017] LCMLQ 95, 114-15.

${ }^{141}$ Jonathan Morgan, 'The Penalty Clause Doctrine: Unloveable but Untouchable' [2016] CLJ 11, 12; see also Summers (n 140).

${ }^{142}$ For discussion, see Rowan (n 133) 449-55.

${ }^{143}$ Quadrant Visual Communications Ltd v Hutchison Telephone (UK) Ltd [1993] BCLC 442, 451 (CA) (Stocker LJ).

144 ibid 452 (Butler-Sloss LJ). 
compensation for breach cannot simply seize assets belonging to the breaching party. In general, at least, she must first convince a court that the money is owed, and, even then, must rely on court officers to ensure satisfaction against a recalcitrant defendant.

Contracting parties may, however, seek to depart from the usual position, by providing for self-help entitlements to repossess property in a contract of sale, lease, or mortgage, as a remedy for non-payment. Here, too, freedom of contract often yields to the social interest in keeping disputes under control. Thus, in a residential tenancy, English law bars re-entry by a landlord without a court order. ${ }^{145}$ Adopting a similar rule, and departing from the prior common law rule that allowed self-help, an American court explained that there is 'no cause to sanction such potentially disruptive self-help where adequate and speedy means are provided for removing a tenant peacefully through judicial process' ${ }^{146}$ In this particular context, the law simply bars the use of this form of self-help, motivated in part by the fear that repossession attempts without a court's imprimatur will spark violence. ${ }^{147}$

In some other kinds of transactions, self-help repossession is allowed, but the law seeks to minimize its costs by placing a duty on the creditor to refrain from sparking a violent confrontation. In English law a mortgagee can repossess real property in the event of default without a court order, but only so long as her entry is 'peaceable'. ${ }^{148}$ While landlords of commercial premises may seek repossession without a court order, they risk being found guilty of a criminal offense unless they can gain possession without using force. ${ }^{149}$ In the area of consumer goods sold on credit, American jurisdictions may not be doing enough to

\footnotetext{
${ }^{145}$ Protection from Eviction Act 1977, s 2.

${ }^{146}$ Berg $v$ Wiley, 264 NW2d 145, 151 (Minn 1978).

${ }^{147}$ See Catherine Sharkey, 'Trespass Torts and Self-Help for an Electronic Age' (2009) 44 Tulsa L Rev 677, 683: 'The law seems on solid, uncontroversial ground in discouraging self-help where it would lead to violence or a breach of peace'). For some doubt about the significance of violence-prevention in shaping this area of law Adam B Badawi, 'Self-Help and the Rules of Engagement' (2012) 29 Yale J on Regulation 1.

${ }^{148}$ Ropaigealach v Barclays Bank Plc [2000] QB 263 (CA).

${ }^{149}$ See Criminal Law Act, 1977, s 6.
} 
discourage violence arising from repossession. The U.C.C. permits a secured lender to repossess collateral without a court order, but only if the lender 'proceeds without breach of the peace'. ${ }^{150}$ Still, repossessions of vehicles in the United States sometimes end with property damage, and all too frequently conclude with serious injuries or death to the vehicle owner or the agent sent to repossess the property. ${ }^{152}$

\section{Transfer of Contractual Claims to Non-Parties}

Let us turn now to an area of contract law where the interest in conflict-management has perhaps been given insufficient weight in recent years: the law of assignment. Parties may want to transfer contractual claims to third parties for several reasons, particularly to finance credit. Historically, however, the desire to assign claims came up against a powerful countervailing idea, based on the conflict-minimization imperative. The idea was that legal claims should be considered personal to the original parties, and the same idea underpinned the much-eroded prohibitions on maintenance, champerty, and barratry, whose purpose was to limit third-party involvement in litigation and thereby to reduce its incidence. ${ }^{153}$ Influenced by this idea, the common law generally refused to recognize assignments of claims.

According to Coke, allowing the transfer of claims to 'strangers' 'would be the occasion of multiplying of contentions and suits'. ${ }^{154}$

The common law's near-absolute hostility to assignment is now understood to be an overreaction. But the current legal position may have swung too far in the other direction. As a result of equity's intervention, English law is now strongly committed to assignability. The

\footnotetext{
${ }^{150}$ UCC § 9-609(b)(2). The lender may be liable even if the breach of the peace results from the borrower's resistance. MBank El Paso v. Sanchez, 836 S.W.2d 151 (Tex. 1992).

${ }^{152}$ See National Consumer Law Center, Repo Madness: How Automobile Repossessions Endanger Owners, Agents and the Public (NCLC 2010).

${ }^{153}$ Lord Neuberger, 'From Barretry, Maintenance and Champerty to Litigation Funding' (Harbour Litigation Funding First Annual Lecture, London, 8 May 2013) 〈https://www.supremecourt.uk/docs/speech-130508.pdf> last accessed June 8, 2017, para 30.

${ }^{154}$ Lampet's Case (1613) 10 Co Rep 46b, 48a; 77 ER 994, 997.
} 
normal rule is now that assignment of a debt claim is permissible even if the parties have not specifically provided for it. ${ }^{155}$ And while it is officially permissible for the parties to expressly prohibit assignment by a clause in their contract, ${ }^{156}$ courts have shown themselves remarkably willing to allow creditors to evade such clauses using the simple expedient of a declaration of trust. ${ }^{157}$ The original policy reason against assignment seems now to have been almost forgotten: contemporary writers on assignment often treat the common law's position on assignment as the product of unreasoned formalism. ${ }^{159}$ This assumption is apparently shared by government: new regulations will soon guarantee enforceability of assignments of receivables even in the teeth of express clauses barring assignment. ${ }^{160}$

The conflict-minimization perspective, however, suggests that we should treat with caution English law's current extreme enthusiasm for assignment. When parties agree to contracts, they typically imagine that a subsequent contractual dispute will be dealt with in the context of the parties' existing and continuing relationship. ${ }^{162}$ That relationship will often impose economic, moral, and reputational limits on, for example, the creditor's urge to squeeze an unfortunate debtor faced with unforeseen payment difficulties. But once the claim is transferred to someone else, the relationship no longer restrains the excessive pursuit of contractual entitlements. Particularly problematic is the assignment of debt claims to parties

\footnotetext{
${ }^{155}$ See Hugh Beale (gen ed), Chitty on Contracts $\left(32^{\text {nd }}\right.$ edn incorporating $1^{\text {st }}$ supplement, Sweet \& Maxwell 2017) para 19-057.

${ }^{156}$ Linden Gardens Trust Ltd v Lenesta Sludge Disposals Ltd [1994] 1 AC 85, 106 (HL).

${ }^{157}$ Barbados Trust Co v Bank of Zambia [2007] EWCA Civ 148, [2007] 1 Lloyd's Rep. 495.

${ }^{159}$ For example, one text states that ' $[\mathrm{t}]$ he reason for the common law rule against assignment is, essentially, historical'. Marcus Smith, The Law of Assignment: The Creation and Transfer of Choses in Action (OUP 2007) para 5.05.

${ }^{160}$ Draft Business Contract Terms (Restrictions of Assignment of Receivables) Regs 2017. The stated justification is that small and medium-sized businesses should be able to raise credit by factoring or otherwise assigning their debt claims, even if they have explicitly agreed to forego the opportunity. For a fuller list of reasons proffered for depriving non-assignment clauses of effect, see Hugh Beale, Louise Gullifer, and Sarah Paterson, 'A Case for Interfering with Freedom of Contract? An Empirically Informed Study of Bans on Assignment' [2016] JBL 203, 207-08.

${ }^{162}$ See Beale, Gullifer, and Paterson (n 160) 221.
} 
whose sole business is debt-collection. Such parties have no reputational need to act reasonably in the context of a dispute. 'Vulture funds' who assume rights under contracts lack the incentive to temper their litigation behaviour. Indeed, shorn of any kind of business apart from debt enforcement, they have the strategic incentive to promote a reputation for extreme tactics in the hope that they will frighten debtors into payment, regardless of the validity of the debts. ${ }^{163}$ Some debtors may simply capitulate; others will fight back. At the seedier end of the market, debt collection companies who purchase bad debts appear to be significantly more likely than the original debtors to turn to violence in the pursuit of money. ${ }^{164}$

These considerations would not justify a rule banning assignment of contractual claims. Subject to generally-applicable caveats about inequality of bargaining power and surprising terms in standard form contracts, we can expect commercial parties who sign up explicitly for assignability to have weighed the costs against the benefits. But the need to minimize conflict does suggest that the law should be less ready to presume assignability where the parties have not expressly agreed to it. Most of all, the argument from conflict-minimization provides a significant reason for non-assignment clauses to be respected rather than overridden.

\section{E. Strict Liability}

Liability for breach of contract in common law jurisdictions is generally not based on fault. ${ }^{165}$ Except in narrow circumstances where a court will find a contract to be frustrated, a

\footnotetext{
${ }^{163}$ In the particular context of sovereign debt, the U.K. Parliament responded to these concerns by passing the Debt Relief (Developing Countries) Act 2010, which limits the amount that vulture funds can recover in the U.K. courts.

${ }^{164}$ See Jake Halpern, Bad Paper: Chasing Debt from Wall Street to the Underworld (Farrar, Straus, and Giroux 2014).

165 Though the starting point in civil law systems is that fault is necessary for contractual liability, the practical differences between the civil law and common law may not in the end be so great. See Solene Rowan, 'Fault and Breach of Contract in France and England: Some Comparisons' (2011) 22 European Business L Rev 467.
} 
breaching party is liable for failure to perform or for poor performance even though she took all due care. Moreover, while the mitigation rules sometimes amount to something similar, there is, in common law jurisdictions, generally no defence of contributory negligence. ${ }^{166}$ Some critics have seen in this general fault-insensitivity a divergence from morality or from the demands of economic efficiency. ${ }^{167}$

From a conflict-reduction perspective, however, strict liability is less puzzling. Keeping fault out of contractual adjudication may have its downsides, but it makes disputes less costly and relationships less acrimonious. Economic analysts have captured part of the reason strict liability reduces the costs of disputing. Breaches of strict liability rules are typically more readily observable and verifiable than breaches of standards that turn on fault. Other things being equal, liability based on fault leads to more potential arguments, more litigation, and less effective contracts. According to Robert Scott, '[t]he fact that fault regimes increase the likelihood and costs of disputes explains why parties may prefer contracts that only crudely encourage efficient behavior but significantly reduce the contracting costs of enforcement' ${ }^{168}$

This economic understanding of litigation costs provides an important insight. But it should be supplemented by a richer understanding of the dynamics of contractual relationships and disputes. In a useful start, Shiffrin has recently claimed that strict liability 'reduce[s] potential sources of conflict between the parties'. ${ }^{169}$ Under strict liability, the promisee is relieved of a reason to monitor the promisor's conduct closely. She need not scrutinize the promisor's efforts to assess whether any potential failure to perform is down to the promisor's fault. The absence of intrusive scrutiny reduces the incidence of potentially troublesome flashpoints and encourages a more cooperative relationship of trust between the

\footnotetext{
${ }^{166}$ See Forsikringsaktieselskapet Vesta v Butcher [1986] 2 All ER 488 (CA).

${ }^{167}$ See Smith (n 9) 376-77.

${ }^{168}$ Robert E Scott, 'In (Partial) Defense of Strict Liability’ (2009) 107 Mich Law Rev 1381, 1392.

${ }^{169}$ Seana Valentine Shiffrin, 'Enhancing Moral Relationships Through Strict Liability' (2016) 66 UTLJ 353.
} 
parties. Liability based on fault, on the other hand, contributes to a culture of contractual blame. The attribution of blame is likely to lead to a downward spiral, contributing to ruptures in the relationship, to prolonged conflict, lingering mistrust, and mutual enmity.

In the rather different, but analogous, context of marriage law, similar considerations support the trend towards marginalizing questions of fault on divorce. 'No-fault' divorce, available in most American jurisdictions, is 'a more civilized alternative to the adversarial model that has decreased the acrimony and hostility between spouses'. ${ }^{171}$ In England, by way of contrast, unless the couple has been living apart for at least two years, divorce must be based either on adultery or 'unreasonable behaviour' ${ }^{172}$ Campaigners argue that this faultbased divorce system creates conflict, makes it more difficult to reach an agreed settlement, burdens the courts, and harms the couple's children. ${ }^{173}$ While the context of economic exchange that generally characterizes contract law is admittedly distinct, the fundamental point remains that, whatever the costs of foregoing this inquiry, there is some benefit to the parties, and to others, in avoiding adjudication of questions of fault.

\section{F. Rules, Standards, and Settlements}

If dispute-reduction is one of contract law's goals, doctrinal rules should, other things being equal, seek to induce parties to settle their differences out of court. Settlements reduce the costs of disputing, most obviously, by removing the need for the parties to invest further resources in litigation. They also save court resources, freeing up scarce judicial attention to be used where it is needed elsewhere. Enthusiasts for settlements also claim that they typically have greater legitimacy in the eyes of the parties than adjudicated outcomes, that

\footnotetext{
${ }^{171}$ Sanford N Katz, Family Law in America (2nd edn, OUP 2015) 95.

172 Matrimonial Causes Act 1973, s 1. The unsatisfactory state of English divorce law on this score was recently highlighted by the Court of Appeal. Owens v Owens [2017] EWCA Civ 182.

${ }^{173}$ Resolution, Manifesto for Family Law (2015) 20-21.
} 
they are more likely to be complied with, and they are more likely to leave the parties satisfied. ${ }^{174}$

Contract law scholars sometimes make arguments about would best encourage parties to settle their differences out of court rather than litigate them. ${ }^{175}$ But there is no consensus as to how best to do it. One overarching disagreement is whether 'rules' or 'standards' are more likely to induce settlement in the event of dispute. On one view, crisp, clear contract law rules are more likely to lead to harmony between the parties. Scott's article on adjustments to long-term contracts provides an example. ${ }^{178} \mathrm{He}$ rejects claims that courts should assert a power to adjust contracts when unexpected events happen. Rather than trying to incorporate flexible relational norms into legal adjudication, courts should apply predictable, binary rules. The point is not that parties should always perform the original terms of the contract; the point, rather, is that the parties themselves should settle their dispute and decide how to renegotiate the deal. The best courts can hope to do is provide a clear baseline for the parties; unpredictable judicial practices will only increase contracting costs. Scott thus contends that legal certainty is more likely to help the parties to continue their cooperative relationship.

Another view, championed by Macaulay, argues that the best way for courts to induce consensual settlement of disputes is instead to apply broad, unpredictable standards. ${ }^{179}$ Macaulay argues that the goal of much ${ }^{180}$ contract law should be to induce 'acceptable, if not

\footnotetext{
${ }^{174}$ For a critical review of the claimed advantages of settlement, see Marc Galanter and Mia Cahill, “"Most Cases Settle": Judicial Promotion of Settlements’ (1994) 46 Stanford L Rev 1339.

${ }^{175}$ Mark Gergen has argued that some contract modification rules help to induce settlements. In cases of honest dispute over what performance the contract requires, 'the law prods parties to resolve their dispute out of court'. Mark Gergen, 'A Theory of Self-Help Remedies in Contract' (2009) 89 BU L Rev 1397, 1399.

${ }^{178}$ Robert E Scott, 'Conflict and Cooperation in Long-Term Contracts' (1987) 75 California L Rev 2005, 2051.

${ }^{179}$ Stewart Macaulay, 'The Real Deal and the Paper Deal: Empirical Pictures of Relationships, Complexity and the Urge for Transparent Simple Rules' (2003) 66 MLR 44, 67-79. See also Stewart Macaulay, 'Relational Contracts Floating on a Sea of Custom? Thoughts about the Ideas of Ian Macneil and Lisa Bernstein' (2000) 94 Northwestern U L Rev 775, 803: 'Perhaps a qualitative messy system deters parties from using the courts and sometimes provokes settlements that reach the least bad result'.

${ }^{180}$ Macaulay states that consumer cases require a different approach. Macaulay, 'Real Deal' (n 179) $77 \mathrm{fn} 100$.
} 
ideal, settlements'. ${ }^{181}$ If parties shift from being contractual partners to adversaries in litigation, their relationship of trust and reciprocal obligation is likely to fall apart. An expensive and unpredictable legal system, particularly where courts are willing to refashion contractual language in the light of subsequent circumstances, may be better than a system where the parties have clear and easy-to-enforce rights; the lack of predictability frightens parties off litigation. As Macaulay admits, his claim has an air of paradox. The legal system holds itself out as willing and able to solve the parties' disputes, but, in reality, discourages them from availing of its services. Still, '[i]n all but unusual situations', Macaulay contends, 'flexible doctrine will provoke settlements ... With all of its flaws, such coerced cooperation may be the least bad solution in many situations' ${ }^{182}$

This article is not the place to resolve the debate between Scott and Macaulay. Macaulay's claim that open-ended standards are more likely to induce settlement is, he concedes, based on hunch and anecdote rather than rigorous empirical evidence; something similar might be said about Scott's opposing viewpoint. For present purposes, the point is to highlight what Scott and Macaulay share: the view that inducing settlement, and thereby limiting conflict between the parties, should be a goal for contract law.

\section{Conflict-Minimization as a Justifiable Goal for Contract Law}

But is it right to consider the minimization of conflict a goal for contract law at all? Here, as in other fields, ${ }^{183}$ arguments in favour of stability can be met with powerful counterarguments. There is, in particular, a perceived danger that, in the pursuit of peace, the law will lose sight of justice. One way of expressing this concern is to say that, if a legal system bases its

\footnotetext{
181 ibid 70.

182 ibid 45, 79.

${ }^{183}$ Analogous questions arise in political philosophy over what Rawls called the 'problem of political stability'. John Rawls, Political Liberalism (Columbia UP 1993).
} 
decision to recognize legal claims on the fact that litigation is preferable to extra-legal retaliation, such recognition is tantamount to 'buying off' an unworthy retaliatory urge. ${ }^{184}$ An alternative way of stating a similar concern would be to rely on Seana Shiffrin's contention that contract law must be consistent with the maintenance of a moral culture of promising. ${ }^{185}$ Too great a focus on minimizing conflict, for example by encouraging out-of-court settlements over public adjudication, might contribute to the erosion of such a moral culture. Yet another way to voice this kind of worry is to point out that pursuing social stability as an end in itself tends to reinforce the interests of those who hold greater power and resources. To take a concrete example from the world of contractual relationships, supply arrangements between UK supermarkets and their suppliers are said by some suppliers to be marked by a climate of fear, in which suppliers are afraid to complain about the misbehaviour of supermarkets. ${ }^{186}$ In such circumstances, conflict may be minimized, but the resulting state of affairs is far from attractive. If the supermarkets are unwilling to keep their contracts, we might say, the law should be facilitating more disputes between the parties.

For some commentators on recent trends in civil justice, this danger - that the desire to reduce conflict might frustrate the law's underlying purposes - is embodied in the policy of promoting out-of-court settlement. Supporters and critics alike agree that a sea change has occurred in the way that government and the judiciary thinks about civil justice in recent decades. ${ }^{187}$ Courts, previously understood as third-party adjudicators whose role is to provide

\footnotetext{
${ }^{184}$ John Finnis has pressed a similar criticism against civil recourse theories. John Finnis, 'Natural Law: The Classical Tradition' in Jules L Coleman, Kenneth Einar Himma, and Scott J Shapiro (eds), Oxford Handbook of Jurisprudence and Philosophy of Law (OUP 2002) para 26. This criticism is not applicable to all civil recourse theories, however, most of which do not depend on characterizing recourse as a means for getting revenge. See Andrew S Gold 'The Taxonomy of Civil Recourse' 39 Florida State U L Rev 65, 75.

185 Shiffrin (n 10).

${ }^{186}$ Groceries Code Adjudicator, Groceries Code Adjudicator: Annual Report and Accounts, 1 April 2016-31 March 2017 (2017) 21.

${ }^{187}$ Eg, Carrie Menkel-Meadow, 'For and Against Settlement: Uses and Abuses of the Mandatory Settlement Conference’ (1985) 33 UCLA L Rev 485; Hazel Genn, Judging Civil Justice (CUP 2010).
} 
judgment, are now directed to encourage parties end their disputes by agreement, including by ordering mediation and other forms of alternative dispute resolution. Too great an emphasis on dispute resolution, the critics say, undermines the pursuit of public values through litigation. ${ }^{188}$

This concern is certainly relevant to contract law. Macaulay, who, as we saw above, has written of the advantages of settlements of contract disputes, has also noted their downsides: 'insofar as the law of contract is thought to advance social norms other than the peaceful resolution of disputes, a system of negotiation will defeat those values'. ${ }^{189}$ Commentators worry, moreover, that dispute resolution outside the courts hinders the important public good of clarifying and developing rights. ${ }^{190}$ This concern is not limited to circumstances of unequal bargaining power between the parties; the Lord Chief Justice recently argued that the prevalence of commercial arbitration undermines the development of the common law, stymies its ability to provide certainty, and prevents it from adapting to changing business practices. ${ }^{191}$ These considerations should be sufficient to convince anyone that a system of contract law that took conflict-minimization as its sole goal would be unacceptable. While one can imagine a system of litigation that regards itself solely as a conflict-management process, such a system would be appropriate only to what Mirjan Damaška has called a 'reactive state' with no goals of its own. ${ }^{192}$

But this article's claim is the more modest one that conflict-minimization is one of the values to which contract law should answer. Other things being equal, avoiding the negative

\footnotetext{
188 Owen Fiss, 'Against Settlement' (1984) 93 Yale LJ 1073.

${ }^{189}$ Stewart Macaulay, 'Elegant Models, Empirical Pictures and the Complexities of Contract' (1977) 11 Law and Society Review 507, 524.

${ }^{190}$ Mulcahy (n 94).

191 Thomas (n 96).

192 Mirjan R Damaška, The Faces of Justice and State Authority: A Comparative Approach to the Legal Process (Yale UP 1991) 73.
} 
consequences of conflict brings about a gain for human well-being. Conflict-minimization entails harms avoided or, at least, it means that otherwise wasted time and effort spent wrangling over the terms of economic exchange can be put to some more useful purpose. True, the law should not, even in principle, try to reduce the costs of disputes to zero. The law should be seeking to facilitate the optimal level and kinds of dispute. Some costs must be incurred to reap significant benefits, in the shape of better deterrence of wrongful behaviour, the facilitation of beneficial transactions, contributions to distributive justice, and so on. But, from this perspective, if the law can decrease the harms resulting from disputes without unduly compromising on other goals, then it should do so. Where the parties to an agreement for economic exchange are of roughly equal strength, this is often likely to be the case: the avoidance and early settlement of disputes is, in such cases, likely to be mutually beneficial rather than the result of one party imposing its will on the other.

Conflict-minimization is most obviously congenial to instrumentalist accounts, those that seek contract law's value in the good consequences that it brings about. ${ }^{194}$ More subtly, my account also shares something with civil recourse theories of private law. While civil recourse theorists are a diverse bunch, ${ }^{195}$ they unite in stressing the significance of private rights of action to understanding private law. ${ }^{196}$ Private rights of action permit, but do not require, the victim of wrongdoing to act against the wrongdoer: they give the victim a power to act against the wrongdoer through the state. But the victim of wrongdoing may choose not to exercise that power; she may also choose to give it up in exchange for an agreed settlement. In this way, civil recourse theory emphasises a feature of private law (including contract law)

\footnotetext{
194 See Murphy (n 2). Those committed to economic efficiency as contract law's goal could certainly accommodate conflict-minimization as an aspect of that goal. As Murphy makes clear, however, it is possible to embrace an instrumental account of contract law's value without taking economic efficiency as a social good. ibid $162-63$.

195 See Gold (n 184).

${ }^{196}$ Benjamin C Zipursky 'Rights, Wrongs, and Recourse in the Law of Torts' Vanderbilt L Rev 1, 80- 83.. See Gold (n 184) 66-68.
} 
that is central to conflict-minimization. By leaving it to the victim to commence an action for breach, contract law avoids the creation of a legal dispute where the parties are content to proceed without one. And by allowing the victim to cease a claim for breach after having commenced it, contract law facilitates the consensual termination of disputes.

In some respects, however, my argument clashes with the commitments of some particular civil recourse theorists. The minority of civil recourse theorists who view private law liabilities as a means for getting revenge will take issue with my claim that contract law aspires to replace, rather than effectuate, vengeance. ${ }^{197}$ As another point of contrast, the argument of this article is avowedly instrumental, whereas many proponents of civil recourse theory reject instrumentalism as a means of understanding private law. ${ }^{198}$

Is it possible to accommodate conflict-minimization considerations within a noninstrumental account of contract law? To a large extent, this will depend on the content of the particular non-instrumental account in question. For a committed Kantian, for example, the fact that some rule or practice of contract law will reduce conflict more generally is simply irrelevant to the content of the private law relation between the two contracting parties. Some degree of inconsistency between the conflict-minimization imperative and deontological perspectives is unavoidable. But the clash between conflict-minimization and deontological perspectives may be less jarring than it first seems. ${ }^{199}$ Deontological theories

\footnotetext{
${ }^{197}$ See above notes 114 and 132 .

${ }^{198}$ Most notably, Goldberg and Zipursky find instrumentalism in tort law 'woefully deficient'. ibid. at 605. John CP Goldberg and Benjamin C Zipursky, 'Civil Recourse Defended: A Reply to Posner, Calabresi, Rustad, Chamallas, and Robinette’ (2013) 88 Indiana LJ 569, 605. Goldberg and Zipursky posit a natural privilege of the victims of wrongdoing in the state of nature to respond to wrongdoing. ibid. On their view, the state has a duty to the victims of wrongdoing to replace the privilege of self-help with an alternative means of recourse; the creation and maintenance of a system of tort law fulfils this duty. ibid 572-73. By contrast, I do not mean to base contractual liability on the pre-political entitlements of persons in the state of nature. Goldberg and Zipursky do say that one of a plurality of goods that comes from having tort law is 'its contribution to the maintenance of civil order and civil society', but this statement is distinct from their (non-instrumental) theory of tort law. ibid. 592.

${ }^{199}$ My suggestion here is somewhat analogous to Schwartz and Markovits's attempt to reconcile 'efficient breach' with promissory morality. Schwartz and Markovits (n 100).
} 
of contract law in their different forms take as their core notion the duty to abide by the terms of one's promise or agreement. ${ }^{200}$ Much of contract law consists in interpreting the meaning of promises or agreements where the parties have not made an express choice about their rights and duties. Courts aiming to be faithful to the implicit meaning of contractual promises or agreements will pay regard to conflict-minimization because the parties themselves typically consider it a significant aim. As Ian Macneil has argued at the level of theory, ${ }^{202}$ and Stewart Macaulay has shown empirically, ${ }^{203}$ contracting parties typically adhere to norms requiring cooperation, flexibility, and compromise in the face of conflict. And they often write conflict-soothing provisions, like mediation agreements, into their contracts. Typically, if asked, the parties would agree to the law's efforts to control subsequent disputes, because doing so is likely to serve their joint interests. More than elsewhere, the concern that focusing on conflict-minimization will impair other goals is often muted in contract disputes. ${ }^{204}$ In many circumstances, there is no real clash between peace and justice. Pursuing conflictminimization is, instead, part of what it means for a court to do justice.

\section{Conclusion}

Contract law is worth having in significant part because it minimizes the negative consequences of conflict. The value of conflict-minimization is not uniquely relevant to contract law. But in this particular area of law, recent trends in civil justice may not be so deeply at odds with the underlying purposes of substantive law as is sometimes claimed. Still, taking conflict-minimization as a goal for contract law gives rise to a host of challenging questions. To what extent does contract law in its current form actually achieve this goal?

\footnotetext{
${ }^{200}$ See Ripstein (n 1); Fried (n 1); Barnett (n 1).

202 Macneil (n 18).

${ }^{203}$ Macaulay (n 11, 21, 85, 179).

${ }^{204}$ See Mirjan R Damaška, 'Truth in Adjudication' (1998) 49 Hastings LJ 298, 304 (remarking that the disputeresolution paradigm is understood to be dominant in small contract disputes with no effects on third parties).
} 
Exactly what sort of shadow does contract law cast on settlement negotiations? ${ }^{206}$ How might legal doctrine, judicial practice, and lawyerly culture be improved so as to contribute to the goal of reducing the negative consequences of conflict? To serve this goal, to what extent should the private law of contracts be supplemented by regulatory action? How much do the answers to these questions depend on the kind of contractual dispute under consideration? The aim of this article has been to establish that these questions are worth pursuing.

${ }^{206}$ See Robert H Mnookin and Lewis Kornhauser, 'Bargaining in the Shadow of the Law: The Case of Divorce' (1979) 88 Yale LJ 950. 